\title{
Role of temperature in the biomass steam pyrolysis in a conical spouted bed reactor
}

\author{
Enara Fernandez a, Laura Santamaria a , Maider Amutio a, Maite Artetxe a , Aitor Arregi a , \\ Gartzen Lopez ${ }^{\text {a, b, * }}$, Javier Bilbao ${ }^{\text {, }}$, Martin Olazar ${ }^{\mathrm{a}}$ \\ a Department of Chemical Engineering, University of the Basque Country UPV/EHU, P.O. Box 644, E48080, Bilbao, Spain \\ ${ }^{\mathrm{b}}$ IKERBASQUE, Basque Foundation for Science, Bilbao, Spain
}

\section{A R T I C L E I N F O}

\section{Article history:}

Received 21 June 2021

Received in revised form

10 September 2021

Accepted 12 September 2021

Available online 14 September 2021

\section{Keywords:}

Pyrolysis

Biomass

Conical spouted bed reactor

Bio-oil

Steam

\begin{abstract}
A B S T R A C T
The steam pyrolysis of pinewood sawdust has been conducted in a bench scale plant provided with a conical spouted bed reactor (CSBR). This process is of uttermost relevance for the in-line valorisation of pyrolysis volatiles, specifically for their catalytic steam reforming for hydrogen production. The influence of temperature on the product yields has been analyzed in the $500-800{ }^{\circ} \mathrm{C}$ range. A detailed analysis of the volatile stream (condensable and non-condensable components) has been carried out by chromatographic techniques, and the char samples have been characterized by ultimate and proximate analyses, $\mathrm{N}_{2}$ adsorption-desorption, and Scanning Electron Microscopy.

A high bio-oil yield was obtained at $500{ }^{\circ} \mathrm{C}(75.4 \mathrm{wt} \%)$, which is evidence of the suitable features of the conical spouted bed reactor for this process. As temperature was increased, higher gas and lower liquid and char yields were obtained. Steam was fully inert at low pyrolysis temperatures $\left(500-600{ }^{\circ} \mathrm{C}\right)$, and only had a little influence at $700{ }^{\circ} \mathrm{C}$ due to the low gas residence time in the conical spouted bed reactor. At $800{ }^{\circ} \mathrm{C}$, the reaction mechanism was controlled by gasification reactions.

The composition of the liquid fraction was considerably influenced by pyrolysis temperature, with a less oxygenated stream as temperature was increased. Thus, phenolic compounds accounted for the major fraction at low pyrolysis temperatures, whereas hydrocarbons prevailed at $800{ }^{\circ} \mathrm{C}$. The char obtained in the whole temperature range can be further used as active carbon or energy source.

() 2021 The Author(s). Published by Elsevier Ltd. This is an open access article under the CC BY-NC-ND
\end{abstract} license (http://creativecommons.org/licenses/by-nc-nd/4.0/).

\section{Introduction}

Biomass fast pyrolysis has been regarded as one of the most economically viable processes for the production of renewable fuels and chemicals [1,2]. However, in order to make the process competitive and complementary to fossil fuel based ones, it is vital, on the one hand, to appropriately design the reactor configuration and, on the other hand, to progress on the bio-oil upgrading methods [3]. High bio-oil yields are required for improving the feedstock utilization efficiency (one of the main costs in the pyrolysis process) [3], which are obtained by means of reactors that promote high heat transfer rates, low gas residence times and rapid char separation, such as bubbling and circulating fluidized beds, spouted beds, rotating cones and ablative reactors [4,5]. A literature review conducted by Guedes et al. [6] showed that the highest

\footnotetext{
* Corresponding author. Department of Chemical Engineering, University of the Basque Country UPV/EHU, P.O. Box 644, E48080, Bilbao, Spain.

E-mail address: gartzen.lopez@ehu.es (G. Lopez).
}

average bio-oil yields (above 60\%) are produced in the conical spouted bed reactor, both in laboratory and pilot plant scales for different biomass materials (pine, poplar, eucalyptus, bushes, rice husk, sewage sludge, citrus wastes or algae [7-11]). These high biooil yields are achieved by the vigorous solid cyclic movement in the bed, which confers the aforementioned excellent features upon this reactor for biomass fast pyrolysis [12]. The biomass pyrolysis technology has reached pilot (spouted bed and ablative reactors), demonstration (bubbling fluidized bed and rotating cone) and commercial (circulating fluidized bed) scales, but there are still several challenges to overcome, as are those related to reducing the carrier gas flow rate to facilitate bio-oil collection and the heat carrier amounts to avoid attrition problems, or those dealing with the energy demand of the process $[13,14]$.

Regarding bio-oil upgrading routes, great efforts have been devoted to condition bio-oil (mainly by means of in situ catalytic processes), use it for the production of fuels by hydrodeoxygenation, crack it to produce olefins and aromatics, process it 
in FCC units or use it for the production of hydrogen in steam reforming units [15-18]. However, these processes are not in a commercial scale yet due to technological limitations (mainly catalyst deactivation), scalability issues or low competitiveness with the existing processes [19]. The aforementioned bio-oil upgrading processes can also be carried out by means of "in-line" strategies, in which the volatiles produced in the biomass pyrolysis are treated in a subsequent catalytic process in order to obtain either a partially upgraded bio-oil for later valorisation in conventional refineries or bio-refineries [4], or final products, such as olefins, aromatics or hydrogen.

Hydrogen production from biomass pyrolysis has recently attracted great interest, with the two main strategies being bio-oil steam reforming $[20,21]$ and biomass pyrolysis combined with inline steam reforming of the volatile stream [22-24]. The former is proposed to be carried out in centralized plants where the bio-oil has been collected from delocalized pyrolysis facilities, whereas the later has to be conducted in small centralized units. The utilization of an in-line strategy exhibits several advantages, as it avoids bio-oil collection and re-vaporization, minimizing raw material losses, thereby leading to higher hydrogen productions [23].

The CPWV group from the University of the Basque Country UPV/EHU has developed a continuous biomass pyrolysis and in-line steam reforming process for hydrogen production, consisting of a conical spouted bed reactor for the steam pyrolysis and a fluidized bed for the reforming one [25]. This strategy allows obtaining productions of up to $11 \mathrm{~g}$ of hydrogen per $100 \mathrm{~g}$ of biomass in the feed, but the main drawback is the rapid catalyst deactivation by coke deposition occurring in the steam reforming of biomass pyrolysis derived compounds [26]. In an attempt to overcome this severe deactivation, studies have been performed to design catalysts by selecting the most adequate support [27] and promoters [28], which have led to a significant reduction in the coke deposition. However, due to the complex nature of the pyrolysis volatiles, the deactivation rate of the catalyst is still high and additional strategies need to be designed in order to progress towards the scale up of this process. One of these strategies lies in modifying the composition of the pyrolysis volatiles, specifically of those identified as the main coke precursors [29], by adjusting the pyrolysis temperature.

In the two-step pyrolysis and in-line steam reforming strategy developed by the CPWV group from UPV/EHU, the steam required for the reforming process is introduced in the pyrolysis reactor as fluidizing agent. Previous studies carried out at $500{ }^{\circ} \mathrm{C}$ (temperature at which bio-oil yield is maximized) revealed that steam did not cause any significant change in the yields and properties of the organic volatiles derived from biomass pyrolysis (the differences compared to $\mathrm{N}_{2}$ atmosphere were within the experimental error) [25]. However, when temperature is increased steam will take part in the pyrolysis reactions and change the reaction mechanism, product yields and their properties, with the process becoming gasification at temperatures above $800{ }^{\circ} \mathrm{C}[30,31]$.

Pyrolysis under steam atmosphere has been scarcely studied in the literature. Thus, most of the studies have been conducted in fixed bed reactors at $550{ }^{\circ} \mathrm{C}[32,33], 600{ }^{\circ} \mathrm{C}$ [34] and in the $400-700{ }^{\circ} \mathrm{C}$ range [35], apart from one study in a fluidized bed reactor in the $400-500{ }^{\circ} \mathrm{C}$ range [36], as well as few ones dealing with catalytic steam pyrolysis [37-41]. These studies revealed that steam has a positive impact on the yield of the organic bio-oil, as secondary cracking reactions are reduced and the composition of the bio-oil is improved by decreasing the content of acids and increasing that of aliphatic ones, as well as the $\mathrm{H} / \mathrm{C}$ ratio and the heating value. The current paper aims to study the effect of pyrolysis temperature in the $500-800{ }^{\circ} \mathrm{C}$ range on product yields when steam is introduced as fluidizing agent in a conical spouted bed reactor. Emphasis is placed on the volatile fractions and their properties in order to assess their suitability for the subsequent inline reforming. In addition, the char fraction has also been characterized, as it may have numerous applications [42], which contribute to improving process profitability. Accordingly, the results provided in this study are of uttermost significance for contributing to the proposal of new strategies for improving catalyst stability in the pyrolysis-reforming process by attenuating coke deposition, which is the main challenge to face up in the industrial implementation of the pyrolysis-reforming process.

\section{Experimental}

\subsection{Raw material}

The biomass used in this study has been pinewood (Pinus insignis) sawdust, with a particle size in the $1-2 \mathrm{~mm}$ range (to guarantee a suitable performance of the solid feeding system). Table 1 displays the main characteristic of the raw material, i.e., ultimate analysis (LECO CHNS-932 elemental analyzer), proximate analysis (TGA Q5000IR thermogravimetric analyzer) and higher heating value (HHV) (Parr 1356 isoperibolic bomb calorimeter).

\subsection{Pyrolysis equipment}

The pyrolysis setup is shown in Fig. 1 and consists of a conical spouted bed reactor (CSBR) and devices for feeding the biomass, gases and water, as well as for cleaning the outlet stream, and equipment for detailed analysis of the product stream.

The pyrolysis conical spouted bed reactor has a total height of $298 \mathrm{~mm}$, a conical section of $73 \mathrm{~mm}$ high and a cylindrical section of $60.3 \mathrm{~mm}$ in diameter. The diameter of the bottom is $12.5 \mathrm{~mm}$ and that of the gas inlet $7.6 \mathrm{~mm}$. The design of the reactor has been carried out based on previous biomass pyrolysis studies and ensures a vigorous solid movement, which leads to high heat transfer rates and low gas residence times [8-11,43]. As shown in Fig. 1, the reactor has a lateral pipe for removing char particles from the bed during the pyrolysis runs, thus avoiding char accumulation, and therefore secondary reactions. This char removal process has been described elsewhere [44]. In addition, the reactor is coupled to a gas preheater consisting of a tube filled with stainless steel pipes.

Biomass is fed into the reactor continuously by means of a feeding system that consists of a cylindrical vessel, in which the biomass is placed on top of a piston raised by a shaft. The system is vibrated at the same time as the piston is raised, which discharges the biomass into the reactor through a lateral pipe located at the top of the vessel. A double shell tube cools the discharge pipe to avoid biomass degradation before entering the reactor. In order to avoid steam entering the solid feeding system, a low nitrogen flow rate is fed at the top of the solid feeder.

Steam has been used in this study as fluidizing agent and a HPLC Gilson 307 pump controls its flow rate. Water vaporization is carried out using a heating cartridge, and the produced steam is subsequently introduced in the preheater prior to entering the pyrolysis reactor. The plant also includes nitrogen and air feeding systems.

The pyrolysis volatiles and the steam leaving the reactor pass through a gas cleaning system, i.e., a cyclone and a filter, in order to remove the fine char particles. These elements, together with the pyrolysis reactor, are located inside a forced convection oven to prevent the condensation of the pyrolysis products prior to reaching the liquid separation system. The volatiles that leave the oven are directed towards a double tube condenser, cooled by tap water, and a coalescence filter. 
Table 1

Main characteristics of the pinewood sawdust.

\begin{tabular}{ll}
\hline Ultimate analysis (wt\%) $^{\mathrm{a}}$ & \\
Carbon & 49.33 \\
Hydrogen & 6.06 \\
Nitrogen & 0.04 \\
Oxygen & 44.57 \\
Proximate analysis $(\mathrm{wt} \%)^{\mathrm{c}}$ & \\
$\quad$ Volatile matter & 73.4 \\
Fixed carbon & 16.7 \\
Ash & 0.5 \\
Moisture & 9.4 \\
HHV (MJ kg ${ }^{-1}$ ) & 19.8 \\
\hline a On a dry ash free basis. & \\
b By difference. & \\
c On an air-dried basis. &
\end{tabular}

\subsection{Product analysis}

A sample of the pyrolysis volatiles leaving the gas cleaning system is directed through a line thermostated at $280{ }^{\circ} \mathrm{C}$ (to prevent the condensation of the products) to a gas chromatograph (Agilent 6890, provided with a HP-Pona column and a flame ionization detector) for its on-line analysis. The sample to be introduced in the GC is previously diluted in an inert gas and mixed with $0.075 \mathrm{~mL} \mathrm{~min}{ }^{-1}$ of an external standard (cyclohexane) in order to perform the quantification of the products. It has to be noted that response factors are required for the quantification of oxygenated compounds in a GC provided with a FID detector, which were determined in previous studies [45]. The identification of the products has been carried out by analyzing the collected liquid in a gas chromatograph-mass spectrometer (Shimadzu QP-2010S), using a similar column as in the GC. The non-condensable gases leaving the liquid collection system are analyzed with a micro-gas chromatograph (Varian 4900, equipped with Molecular sieve 5, Porapak, CPSil and Plot Alumina modules). The char fraction has also been characterized based on its ultimate and proximate analyses and determining its higher heating value and specific surface area by $\mathrm{N}_{2}$ adsorption-desorption isotherms. The morphology of the char surface has been analyzed by Scanning Electron Microscopy (SEM) in a JEOL JSM-6400 apparatus.

\subsection{Experimental conditions}

Pyrolysis reactions have been conducted at four temperatures: $500,600,700$ and $800{ }^{\circ} \mathrm{C}$. The biomass feeding rate has been $0.75 \mathrm{~g} \mathrm{~min}^{-1}$ and the one of water $3 \mathrm{~mL} \mathrm{~min}^{-1}$, which results in a S/ $B$ ratio of 4 . These parameters were selected according to previous studies of pyrolysis and in-line steam reforming, as lower S/B ratios lead to lower hydrogen productions and fast deactivation rates in the subsequent reforming step [29]. The pyrolysis bed was made up of $50 \mathrm{~g}$ of silica sand with a particle size in the $0.3-0.35 \mathrm{~mm}$ range, which ensured stable spouting regime with a vigorous solid movement. The good performance of the CSBR for biomass pyrolysis has been reported in previous studies [7-9]. Thus, this reactor provides several advantages compared with other reactor configurations, namely: i) short residence time of the volatiles in the reactor (of around $20 \mathrm{~ms}$ due to the high velocity of the gas, thus minimizing volatile transformation by secondary reactions, and so maximizing the bio-oil yield in the biomass pyrolysis), ii) high heat and mass transfer rates, i.e., the high velocity of both the gas and the solid phases and their countercurrent contact improve heat and mass transfer rates, and iii) rapid removal of the char from the reactor by the segregation of char from sand in the fountain, which allows continuous operation. Besides, its simple design eases the scalability of the pyrolysis process.

Prior to the pyrolysis runs, all the elements of the plant were heated using $2 \mathrm{~L} \mathrm{~min}^{-1}$ of nitrogen as fluidizing agent. Then, the fluidizing gas was switched to water and once temperature had been stabilized, biomass feed was started. Each run was conducted for $10 \mathrm{~min}$ in order to ensure steady state operation, and the

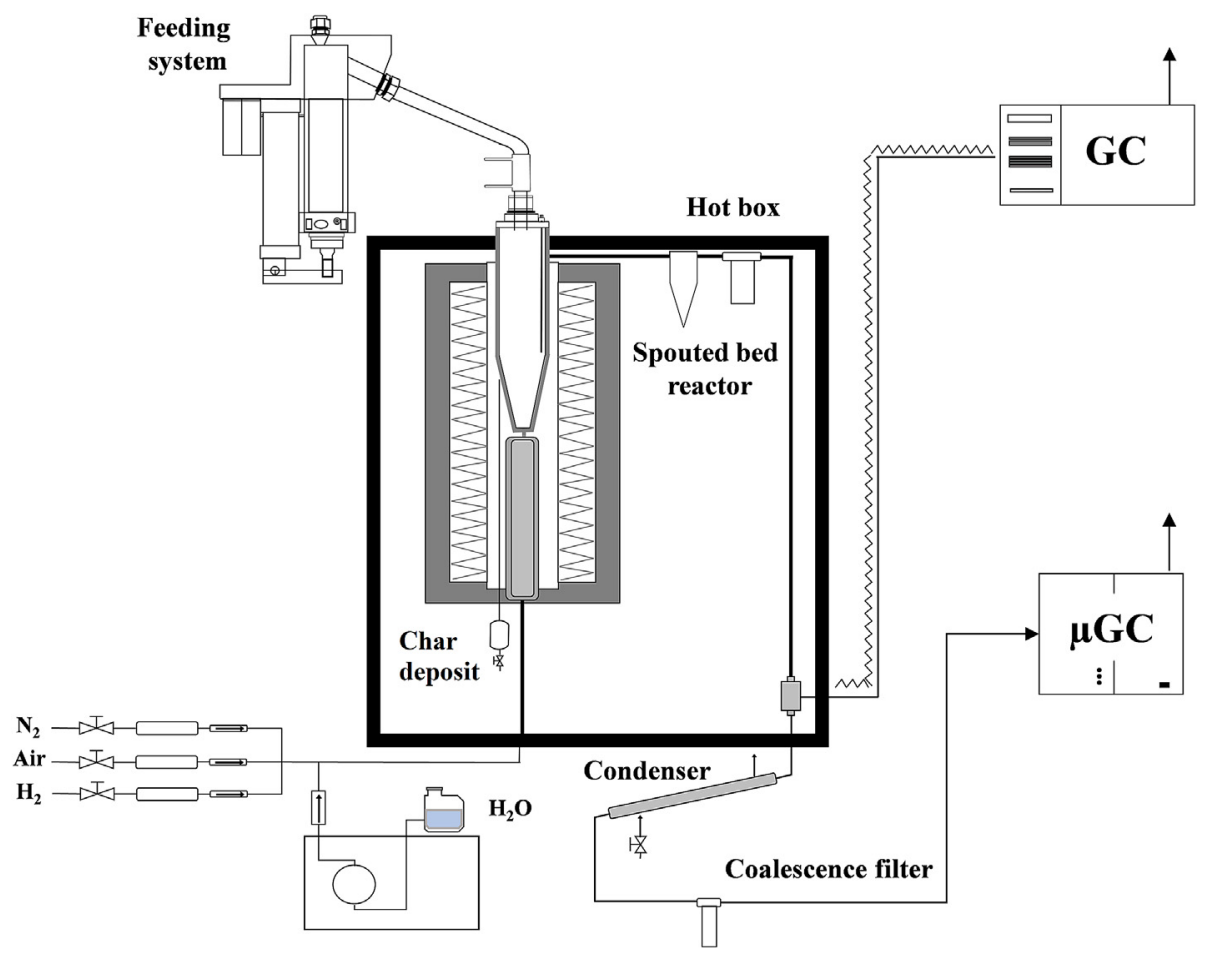

Fig. 1. Scheme of the biomass fast pyrolysis laboratory scale plant. 
volatiles were analyzed on-line by means of the GC and micro-GC. The yield of water is the moisture content in the biomass plus the water formed in the pyrolysis reactions minus the steam reacted in the process. This yield was determined based on $\mathrm{H}$ mass balances by considering the $\mathrm{H}$ contained in the biomass (including moisture) and pyrolysis products. The mass balance has been closed, on the one hand, by measuring the char remained in the reactor plus the amount collected through the lateral pipe and those retained in the cyclone and filter and, on the other hand, by means of the on-line chromatographic analyses, using a given flow rate of the external standard. It is to note that, in all the runs carried out at each temperature, $\mathrm{C}, \mathrm{H}$ and $\mathrm{O}$ mass balance closures were above $95 \%$, with the runs being repeated at least 3 times under the same experimental conditions in order to ensure reproducibility.

\subsection{Reaction indexes}

The yields of the products obtained in the steam pyrolysis at different temperatures have been determined as follows:

$Y_{g a s}=\frac{m_{g a s}}{m_{0}} \cdot 100$

$Y_{\text {bio-oil }}=\frac{m_{\text {bio-oil }}}{m_{0}} \cdot 100$

$Y_{\text {char }}=\frac{m_{\text {char }}}{m_{0}} \cdot 100$

where $m_{\text {gas }}, m_{\text {bio-oil }}$ and $m_{\text {char }}$ are the masses of non-condensable gases, condensable fraction (bio-oil) and char, respectively, and $\mathrm{m}_{0}$ is the mass flow rate of biomass fed into the process.

Besides, in order to analyze the pyrolysis/gasification performance, the following reaction indexes have also been taking into account:

- Gas production ( $\mathrm{P}_{\text {gas }}, \mathrm{Nm}^{3} \mathrm{~kg}^{-1}$ ) by mass unit of biomass fed into the gasification process:

$P_{g a s}=\frac{Q_{g a s}}{m_{0}} \cdot 100$

where $\mathrm{Q}_{\mathrm{gas}}$ is the volumetric flow rate of the gas produced and $\mathrm{m}_{0}$ is the mass flow rate of biomass fed into the process.

- Tar concentration determined as the amount of tar (in mass) contained per $\mathrm{m}^{3}$ of syngas.

Tar concentration $=\frac{m_{\text {tar }}}{Q_{\text {gas }}}$

\section{Results and discussion}

\subsection{Product yields}

Pyrolysis products have been grouped into gas, bio-oil and char fractions and their yields are displayed in Fig. 2. Although we use the term bio-oil for the whole range of temperatures studied, it should be noted that the liquid product obtained at high temperatures, especially at $800^{\circ} \mathrm{C}$, has a nature and composition similar to the tar obtained in biomass gasification $[46,47]$.

The gas was the main fraction at $800{ }^{\circ} \mathrm{C}$, whose yield considerably increased from $7.3 \mathrm{wt} \%$ at $500{ }^{\circ} \mathrm{C}$ to $63.9 \mathrm{wt} \%$ at $800{ }^{\circ} \mathrm{C}$.
Nevertheless, bio-oil was the predominant fraction at 500,600 and $700{ }^{\circ} \mathrm{C}$, but its yield significantly decreased when temperature was increased (from $75.4 \mathrm{wt} \%$ at $500{ }^{\circ} \mathrm{C}$ to $27.2 \mathrm{wt} \%$ at $800^{\circ} \mathrm{C}$ ) due to the secondary bio-oil cracking reactions that promote gas formation $[48,49]$. An increase in temperature led to a reduction in the char yield, from $17.3 \mathrm{wt} \%$ at $500{ }^{\circ} \mathrm{C}$ to $8.9 \mathrm{wt} \%$ at $800^{\circ} \mathrm{C}$. Therefore, below $700{ }^{\circ} \mathrm{C}$, an increase in temperature promotes the devolatilization of biomass components, with temperatures higher than $600^{\circ} \mathrm{C}$ being required to ensure lignin degradation [50]. Moreover, at high temperatures, the presence of steam in the reaction environment promotes char conversion by heterogeneous steam gasification [51,52]. The aforementioned results are consistent with those reported in the literature for lignocellulosic biomass pyrolysis in an inert environment, i.e., the maximum liquid yield is obtained at temperatures in the $450-550{ }^{\circ} \mathrm{C}$ range $[48,49,53]$. Regarding the pyrolysis studies conducted under steam atmosphere, Pütün et al. [35] investigated the effect of temperature on the steam pyrolysis of cottonseed cake in a fixed bed reactor in the $400-700{ }^{\circ} \mathrm{C}$ range and observed a maximum organic liquid yield of $31.7 \mathrm{wt} \%$ at $550{ }^{\circ} \mathrm{C}$, with a significant reduction at $700{ }^{\circ} \mathrm{C}$. Kantarelis et al. [36] conducted the steam pyrolysis of pine and spruce wood mixture in a bubbling fluidized bed reactor at 400,450 and $500{ }^{\circ} \mathrm{C}$. Given the low temperatures used, an increase in this operating parameter had a positive impact on the bio-oil yield, obtaining a maximum yield of $41.6 \mathrm{wt} \%$. Higher liquid yields when a conical spouted bed reactor is used instead of other technologies have already been reported in previous biomass pyrolysis studies [7-11]. The characteristic cyclic movement of the solids confers high heat and mass transfer rates and low gas residence times upon this reactor [12], which hinder secondary cracking reactions.

Analysing the results obtained at the higher temperature range, in which the gas is the predominant fraction, the specific gas productions obtained are 0.38 and $0.67 \mathrm{~m}^{3} \mathrm{~kg}^{-1}$ at 700 and $800{ }^{\circ} \mathrm{C}$ respectively, with tar (or bio-oil) contents being 785 and $264 \mathrm{~g}$ $\mathrm{Nm}^{-3}$. The results obtained in the current study are consistent with the gas production of $0.73 \mathrm{~m}^{3} \mathrm{~kg}^{-1}$ and tar content of $364 \mathrm{~g} \mathrm{Nm}^{-3}$ reported in a previous gasification study in a CSBR at $800{ }^{\circ} \mathrm{C}$ using an S/B ratio of 1 [54]. In fact, an increase in S/B favors gas production, and therefore reduces tar formation due to its reforming $[30,55]$. The low specific gas productions and high tar contents at $700{ }^{\circ} \mathrm{C}$ are evidence of a low reactivity and so low extent of tar

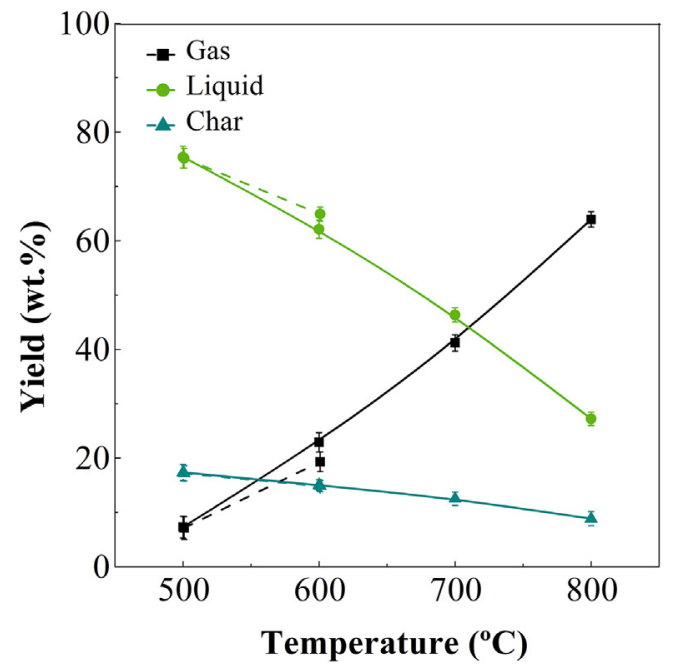

Fig. 2. Product yields obtained in the pinewood pyrolysis process using steam as fluidizing agent in the $500-800{ }^{\circ} \mathrm{C}$ range. (Dash lines correspond to the results obtained in a previous study using $\mathrm{N}_{2}$ as fluidizing agent [7]). 
steam reforming reactions at this temperature, probably due to the short gas residence time in the CSBR, and therefore low rates of the mentioned reactions at this temperature. The studies carried out in the literature at gasification temperatures between 700 and $800{ }^{\circ} \mathrm{C}$ also reveal a remarkable improvement in the gasification performance with temperature, as gas production is $1.2-2$ times higher [56-58] and tar content $0.75-10$ times lower when temperature is increased from the lowest to the highest value in this range $[56,57,59]$. However, the tar contents obtained in the current study are high compared to the ones obtained with other gasification technologies in the literature [30], which is explained by the low residence time of the gas in the CSBR. It should be noted that the tar content in the CSBR was considerably reduced in later studies performed in an improved version of this reactor [60], in which suitable primary catalysts were used [61].

As shown in Fig. 2, a comparison of the results obtained in the current study (using steam as fluidizing agent) with the ones previously obtained shows that the differences observed at $500{ }^{\circ} \mathrm{C}$ are not significant when the same biomass and reactor are used under nitrogen atmosphere at 500 and $600{ }^{\circ} \mathrm{C}$ (higher temperatures were not analyzed in that case because the aim was to maximize the biooil yield) [7]. Similarly, the small differences observed at $600{ }^{\circ} \mathrm{C}$ in the yields of both the gas (a slight increase from $19.5 \mathrm{wt} \%$ with $\mathrm{N}_{2}$ to $22.9 \mathrm{wt} \%$ with steam) and the bio-oil (65.1 wt\% with $\mathrm{N}_{2}$ and $62.1 \mathrm{wt}$ $\%$ with steam) reveal that steam does not play a significant role in the pyrolysis process at this temperature. In fact, steam reforming reactions are highly endothermic reactions and high temperatures are required for their promotion [62].

In the studies carried out in the literature in fixed bed reactors by pyrolyzing cottonseed cake [35], potato skin [32] and almond shell [34] with steam, a positive effect was observed on the organic liquid yields at 550 and $600{ }^{\circ} \mathrm{C}$, with the values being 1.21 and 1.54 times higher than those obtained under nitrogen atmospheres. The authors of these studies concluded that steam is adsorbed on the char surface, inhibiting the adsorption of volatiles and preventing secondary cracking reactions. In addition, steam was also found to react with the products and reduce char formation. Regarding a study conducted in a fluidized bed reactor [36], an increase in the organic liquid yield was observed when steam was in the feed at $500{ }^{\circ} \mathrm{C}$, although the increase was lower than those reported for fixed bed reactors. The organic liquid yield increased from around $37 \mathrm{wt} \%$ when nitrogen was used to $41.6 \mathrm{wt} \%$ for a S/B value of 0.5 , with further increases in the steam/biomass ratio promoting gas formation. However, the differences in the yields obtained in the current study in the conical spouted bed reactor are evidence that steam has a rather low impact, which is explained by the aforementioned short residence time of the gas.

\subsection{Gas fraction}

The gas fraction is composed of $\mathrm{CO}_{2}, \mathrm{CO}, \mathrm{H}_{2}, \mathrm{CH}_{4}$ and $\mathrm{C}_{2}-\mathrm{C}_{4}$ hydrocarbons, as shown in Fig. 3. The yields of all the gaseous compounds increase with temperature (Fig. 3a) due to the promotion of secondary cracking reactions at high pyrolysis temperatures. $\mathrm{CO}_{2}$ is the main gaseous compound at low temperatures, whereas the yield of $\mathrm{CO}$ prevails over $600^{\circ} \mathrm{C}$, which is explained by the predominance of decarbonylation reactions over those of decarboxylation at high temperatures [63]. Moreover, steam reforming reactions are enhanced under steam atmosphere [31] and the equilibrium of water gas shift reaction is hindered at high temperatures [23]. The yield of $\mathrm{C}_{1}-\mathrm{C}_{4}$ hydrocarbons is also increased with temperature due to the enhancement of cracking reactions. $\mathrm{H}_{2}$ yield is low at 500 and $600{ }^{\circ} \mathrm{C}$, but is significant at higher temperatures, especially at $800{ }^{\circ} \mathrm{C}$, as a result of the contribution of steam reforming reactions of biomass derived volatiles. The analysis of the composition of the gaseous stream (Fig. 3b) reveals a change in the trend of the volumetric composition of the gas in the range between 700 and $800{ }^{\circ} \mathrm{C}$. Thus, the concentration of $\mathrm{CO}$ increases steadily from 500 to $700{ }^{\circ} \mathrm{C}$, but decreases at $800{ }^{\circ} \mathrm{C}$. In a similar way, the reduction in $\mathrm{CO}_{2}$ concentration and the increase in that of $\mathrm{C}_{1}-\mathrm{C}_{4}$ hydrocarbons levels off at $800^{\circ} \mathrm{C}$. These results confirm that the reaction pathway at $800^{\circ} \mathrm{C}$ is controlled by gasification reactions. Thus, the steam gasification studies reported in the literature at high temperatures show a decreasing trend in the concentration of $\mathrm{CO}$, methane and $\mathrm{C}_{2}-\mathrm{C}_{4}$ hydrocarbons and an increasing one in that of $\mathrm{H}_{2}$ due to the extent of highly endothermic steam reforming reactions [23,31]. Similar results were obtained by Dascomb et al. [64], who analyzed the steam gasification of wood pellets in a fluidized bed gasifier. They reported that the hydrogen concentration increased at all temperatures up to $850{ }^{\circ} \mathrm{C}$, obtaining a maximum $\mathrm{H}_{2}$ concentration of $51 \mathrm{vol} \%$ at the optimum operating conditions $\left(\mathrm{T}_{\mathrm{fb}}=853{ }^{\circ} \mathrm{C}, \mathrm{S} /\right.$ $\mathrm{B}=2.9, \tau=4.5 \mathrm{~s}$ ).

As shown in Fig. 3, steam has an influence on the composition of the gaseous fraction obtained, as it allows increasing the contents of $\mathrm{CO}_{2}$ and $\mathrm{H}_{2}$ and decreasing those of $\mathrm{CO}$ and hydrocarbons $[55,65,66]$ over those obtained in a previous study using nitrogen as fluidizing agent [7]. This is evidence that steam reforming of gaseous hydrocarbons and the water gas shift reaction are promoted when water is in the feed due to the increase in the steam partial pressure in the reaction environment. In the study carried out by Kantarelis et al. [36] in a fluidized bed reactor at $500{ }^{\circ} \mathrm{C}$, a positive effect was observed when steam was in the feed (with a $\mathrm{S} / \mathrm{B}$ of 0.67), as it led to an increase in $\mathrm{H}_{2}$ and $\mathrm{CO}_{2}$ yields and a decrease in those of $\mathrm{CO}$ and light hydrocarbons.

\subsection{Liquid fraction}

The bio-oil fraction has been characterized by identifying more than 100 compounds, which have been grouped into chemical families. Table 2 shows the detailed composition of the liquid fraction obtained at different temperatures. Besides, the results obtained in a previous pyrolysis study using $\mathrm{N}_{2}$ as fluidizing agent have also been included in order to ease their comparison [7]. Fig. 4 shows the influence of pyrolysis temperature on the yields of the different bio-oil families (Fig. 4a) and phenolic compounds (Fig. 4b).

As observed in Table 2 and Fig. 4a, phenols are the main bio-oil compounds at all the temperatures studies, except at $800{ }^{\circ} \mathrm{C}$ (hydrocarbons are the main fraction at this temperature). In turn, the phenolic group has been divided into three different groups based on their different behaviour: guaiacols (methoxyphenols), catechols (benzenediols), and alkyl-phenols.

As regards alcohols, ketones and saccharides, their concentrations and yields decrease at high pyrolysis temperatures. Light alcohols, such as methanol or glycerol, are favoured at low temperatures, whereas the heavier ones (polycyclic aromatic alcohols) are promoted at high temperatures. A similar trend is observed for furans. Concerning ketones, some of the compounds are only formed at low temperatures (such as acetone or hydroxyacetone), whereas others are mainly produced at intermediate ones.

The fraction of saccharides, mainly composed of levoglucosan, is reduced at high temperatures due to their low thermal stability [67]. Acids and aldehydes peak at intermediate temperatures, but following different trends. Thus, whereas acids peak at $600{ }^{\circ} \mathrm{C}$ to disappear at 700 and $800{ }^{\circ} \mathrm{C}$, aldehydes reach their peak at $700^{\circ} \mathrm{C}$. These compounds are mainly produced from cellulose and hemicellulose pyrolysis through different formation pathways, whose significance depends on the interaction of cellulose and hemicellulose with the lignin and the ashes in the biomass, thus making 

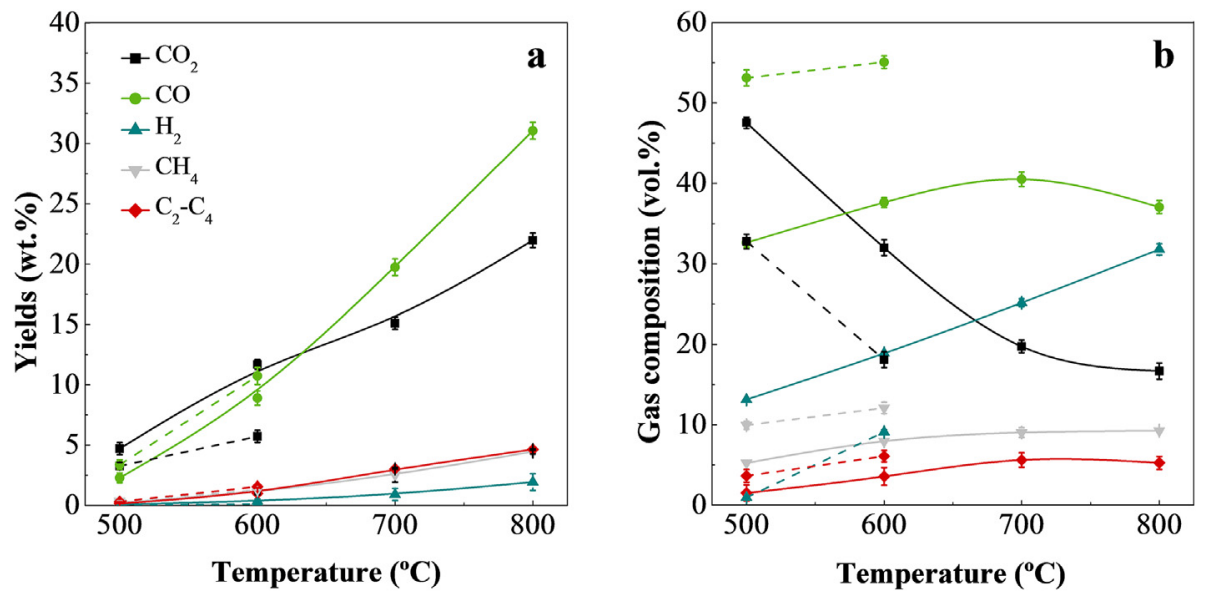

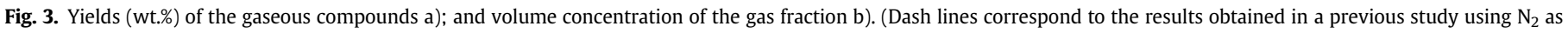
fluidizing agent [7]).

difficult to predict and fully understand their final yields in the biooil obtained [67-69]. The rise in the acid concentration when pyrolysis temperature is increased from 500 to $600{ }^{\circ} \mathrm{C}$ is explained by the preferential formation of acetic acid by deacetylation reactions [36]. As regards aldehydes, the significant increase in their concentration when temperature is raised from 500 to $700{ }^{\circ} \mathrm{C}$ is related to the formation of benzaldehyde-derived compounds. Thus, one of the possible mechanisms involving the conversion of guiacol compounds when temperature is increased is related to their transformation into 2 hydroxybenzaldehyde by homolysis of $\mathrm{O}-\mathrm{H}$ bonds [30]. At high temperatures, these compounds are destroyed and more stable compounds are produced, namely phenol and the hydrocarbon fraction. It should be noted that similar trends have been reported in the literature for the evolution of tar composition with temperature, i.e., from primary (made up of highly oxygenated and ramified compound) to tertiary (condensed non-ramified nor oxygenated aromatics) compounds, when steam or an inert gas have been used [70-72].

The only group whose concentration and overall yield is increased with temperature is the one of hydrocarbons. Thus, it is insignificant at low temperatures, but the prevailing one at $800^{\circ} \mathrm{C}$,

Table 2

Composition of the bio-oil obtained in the pinewood pyrolysis process using steam as fluidizing agent in the $500-800{ }^{\circ} \mathrm{C}$ range (wt.\%).

\begin{tabular}{|c|c|c|c|c|}
\hline Compound & $\begin{array}{l}500{ }^{\circ} \mathrm{C} \\
\text { Steam } / \mathrm{N}_{2}{ }^{\mathrm{a}}\end{array}$ & $\begin{array}{l}600{ }^{\circ} \mathrm{C} \\
\text { Steam } / \mathrm{N}_{2}{ }^{a}\end{array}$ & $700{ }^{\circ} \mathrm{C}$ & $800{ }^{\circ} \mathrm{C}$ \\
\hline Acids & $4.00 / 3.62$ & $7.00 / 3.84$ & 0.00 & 0.00 \\
\hline Aldehydes & $3.29 / 2.56$ & 9.18/6.59 & 16.67 & 0.94 \\
\hline Ketones & $9.64 / 8.46$ & $8.42 / 5.81$ & 5.80 & 0.82 \\
\hline Alcohols & $2.43 / 2.65$ & $2.85 / 2.26$ & 0.75 & 1.04 \\
\hline Polycyclic aromatic alcohols & $0.27 / 0.00$ & $0.00 / 0.00$ & 1.10 & 2.27 \\
\hline Phenols & 21.98/21.89 & 18.16/17.18 & 27.00 & 18.58 \\
\hline Alkyl-phenols & $2.16 / 2.39$ & $3.31 / 1.78$ & 14.72 & 18.58 \\
\hline Catechols & $10.99 / 9.50$ & $13.95 / 12.60$ & 12.28 & 0.00 \\
\hline Guaiacols & $8.84 / 10.00$ & $0.90 / 0.29$ & 0.00 & 0.00 \\
\hline Furans & $3.10 / 4.41$ & $1.89 / 2.32$ & 3.71 & 4.17 \\
\hline Saccharides & $6.03 / 5.92$ & $4.92 / 3.50$ & 3.20 & 0.00 \\
\hline Hidrocarbons & $0.00 / 0.00$ & $0.76 / 0.00$ & 2.14 & 32.20 \\
\hline Non-aromatics & $0.00 / 0.00$ & $0.76 / 0.00$ & 0.81 & 0.00 \\
\hline Light aromatics (BTX) & $0.00 / 0.00$ & $0.00 / 0.00$ & 0.74 & 3.57 \\
\hline PAHs & $0.00 / 0.00$ & $0.00 / 0.00$ & 0.00 & 28.63 \\
\hline Others & $0.09 / 0.08$ & $0.00 / 0.37$ & 1.04 & 0.07 \\
\hline Unidentified & $16.52 / 16.74$ & $16.50 / 16.38$ & 3.75 & 4.73 \\
\hline Water & $32.66 / 33.67$ & $30.32 / 41.75$ & 34.83 & 35.18 \\
\hline
\end{tabular}

${ }^{\text {a }}$ Results obtained in a previous pyrolysis study using $\mathrm{N}_{2}$ as fluidizing agent [7]. which is explained by the destruction of functional species, and therefore by avoiding the formation of oxygenated compounds [49]. At $600{ }^{\circ} \mathrm{C}$, the only hydrocarbons detected are linear ones, whereas at $700{ }^{\circ} \mathrm{C}$, single-ring light aromatics are also formed. However, at $800{ }^{\circ} \mathrm{C}$, polyaromatic hydrocarbons (PAHs), particularly naphthalene and indene, are the main compounds in the organic liquid fraction.

As mentioned before, the phenolic fraction has been divided into three different groups, i.e., guaiacols, catechols and alkylphenols, whose individual yields at different steam pyrolysis temperatures are displayed in Fig. 4b. As observed, catechols are the main phenolic compounds detected in the $500-600{ }^{\circ} \mathrm{C}$ range, and alkyl-phenol yield increases considerably from 500 to $700^{\circ} \mathrm{C}$ due to the formation of methyl-phenol compounds. The yield of guiacols sharply reduces from 500 to $600{ }^{\circ} \mathrm{C}$ (from 6.66 to $0.56 \mathrm{wt} \%$, respectively). Thus, guaicols are transformed into the following compounds: i) catechols by demethylation reactions; ii) o-cresol and 2-hydroxybenzaldehyde by $\mathrm{O}-\mathrm{H}$ bond homolysis; and iii) phenol and carbon monoxide by demethoxylation reactions [67,73]. Moreover, a reduction in the yield of phenolic compounds was observed at $800{ }^{\circ} \mathrm{C}$ due to the full transformation of guaiacol and catechol compounds. Nevertheless, the concentration of alkylphenols in the organic liquid fraction considerably increased ( $18.58 \mathrm{wt} \%$, Table 2 ), with phenol being the main component. It is to note that the overall yield of phenolic compounds sharply reduces as temperature is increased (Fig. 4a), as a result of their decomposition to more stable compounds (aromatics and gases) at high temperatures [30]. At the low temperature range $\left(500-600{ }^{\circ} \mathrm{C}\right.$ ), this decrease is due to the drastic reduction in the yield of guaiacols as temperature is increased, as they are the primary products of softwood lignin decomposition, which are converted into catechols and phenols as temperature is increased above $450{ }^{\circ} \mathrm{C}$ [73].

These results are consistent with the tar compositions reported in the literature for biomass steam gasification, as tar evolves to more stable compounds with temperature $[30,71,74]$. In this regard, several researches have reviewed the change in the composition of the organic liquid products derived from biomass pyrolysis and steam gasification with temperature [30,74,75]. Milne et al. [75] reported that, at low temperatures, i.e., pyrolysis temperature below $500{ }^{\circ} \mathrm{C}$, biomass compounds decompose to primary products made up of oxygenate and condensable organic compounds, such as acids, aldehydes, ketones, furans, alcohols, complex oxygenates, phenols, guaiacols, syringols, and complex phenols. As temperature is being increased to $700{ }^{\circ} \mathrm{C}$, the primary products start to be 

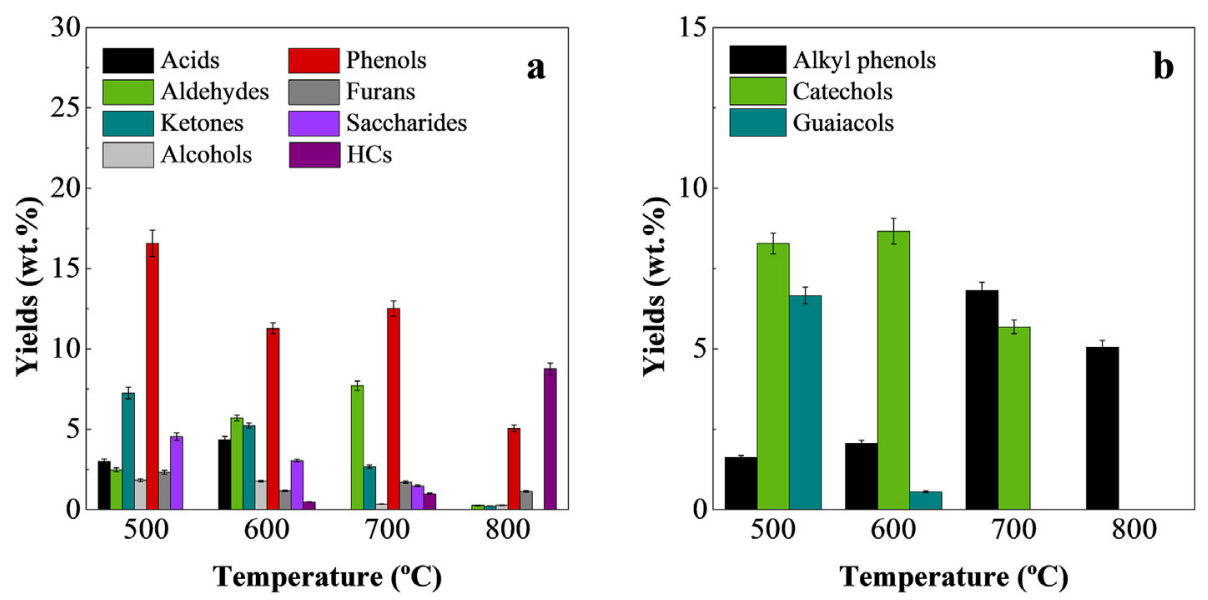

Fig. 4. Influence of steam pyrolysis temperature on the yields of the bio-oil fraction a); and the phenolic compounds b).

converted into secondary ones (composed of benzenes, phenols, catechols, naphthalenes, biphenyls, phenanthrenes, benzofurans and benzaldehydes), and therefore their concentration sharply increases at the same time as primary product concentration decreases. Finally, at high temperatures (over $800{ }^{\circ} \mathrm{C}$ ), primary compounds are fully transformed into alkyl tertiary products (methyl derivatives of aromatics, such as methyl acenaphthylene, methylnaphthalene, toluene, or indene) and condensed tertiary products or polycyclic aromatic hydrocarbons (PAHs).

It should be noted that no significant differences are observed between the composition of the bio-oil obtained in this study at $500{ }^{\circ} \mathrm{C}$ using steam as fluidizing agent and the one obtained in a previous study under $\mathrm{N}_{2}$ atmosphere [7] (See Table 2). At $600{ }^{\circ} \mathrm{C}$, the composition of the organic liquid fraction has certain differences when steam is used as fluidizing agent, as slightly higher concentrations of acids (mainly acetic acid formed by deacetylation reactions), aldehydes (due to the formation of 2hydroxybenzaldehyde), ketones and saccharides (mainly composed of levoglucosan) are obtained. Conversely, a slight decrease in furan concentration is observed. The increase in the saccharide fraction when steam atmosphere is used instead of $\mathrm{N}_{2}$ in the biomass pyrolysis was also reported by Kantarealis et al. [36], who attributed it to the suppression of sugar decomposition/ dehydration reactions (sugars to furans). However, the small differences observed in the bio-oil composition are evidence of the low reactivity of steam in the pyrolysis process at low temperatures.

Moreover, the tar composition obtained in a previous study wherein steam gasification was conducted in a CSBR at $800^{\circ} \mathrm{C}$ with a S/B ratio of 1 [54] is consistent with the results obtained in this study. Thus, in both cases, the primary products derived from biomass pyrolysis are almost fully transformed into secondary and tertiary ones. Moreover, the concentration of heavy ketones $(9 \mathrm{H}-$ Fluoren-9-one), polycyclic aromatic alcohols (1-Naphtalenol), and furans (2,3-dihydrobenzofuran) is also similar in both cases. The phenolic fraction (within the heterocyclic compound group in the previous study) is mostly composed of alkyl-phenols, and its concentration in the tar obtained in this study is considerable higher. Finally, the hydrocarbon fraction is the predominant one in both cases, wherein similar concentrations are obtained for light aromatics (mainly composed of toluene) and light polyaromatic hydrocarbons (with naphthalene being the major compound). As previously mentioned, an increase in S/B ratio from 1 to 4 leads to a decrease in the overall tar yield, although the composition of this organic liquid fraction is not considerable affected.
The composition of the condensable (liquid) product fraction plays a remarkable role in the performance of the reforming step. In fact, the bio-oil composition greatly influences the mechanisms of catalyst deactivation and coke deposition [76]. The aforementioned results clearly reveal the impact of pyrolysis temperature on the bio-oil yield and its composition. Thus, the composition of pyrolysis volatiles may be modified by changing pyrolysis conditions. Furthermore, conversion of bio-oil gaseous products may be promoted by operating at high temperatures, which has a positive impact on the subsequent steam reforming step.

Table 3 compares the ultimate analysis of the liquids obtained at the four temperatures studied. As expected, the liquid produced at higher temperatures is less oxygenated and has higher carbon content due to the aforementioned loss of oxygenated compounds and promotion of hydrocarbon formation. This fact is particularly evident in the runs conducted at $800{ }^{\circ} \mathrm{C}$, wherein hydrocarbon formation prevails. Besides, the high oxygen content in the bio-oil obtained at the lower range of temperatures (500 and $600{ }^{\circ} \mathrm{C}$ ) is a consequence of the high water content of the samples. Conversely, the water content in the organic liquid fraction decreases as temperature is increased due to the higher amount of reacted water (mainly involved in steam reforming reactions), which contributes to the sharp reduction in the oxygen content of the organic liquid sample obtained at $800^{\circ} \mathrm{C}$.

The results shown in Table 3 for the lower range of temperatures $\left(500\right.$ and $600{ }^{\circ} \mathrm{C}$ ) are consistent with those obtained in a previous pinewood pyrolysis study conducted with $\mathrm{N}_{2}$ as fluidizing agent [7]. Similarly, the elemental composition of the organic liquid obtained in this study is also in the range of the typical values for lignocellulosic bio-oils reported in the literature [10,77-79], with carbon content in the 32-48 wt\% range and the oxygen content between 44 and $60 \mathrm{wt} \%$ [77].

\subsection{Char fraction}

The char obtained at different steam pyrolysis temperatures has been characterized, since its valorisation may contribute to enhancing the economic feasibility of this process. Amongst the several char applications, those worth mentioning are related to its use as adsorbent [80,81], activated carbon [82,83], soil amender $[84,85]$ or catalysts support [86]. Accordingly, the ultimate and proximate analyses of the chars obtained are displayed in Table 4. As observed, the proximate analysis results show that fixed carbon increases as temperature is raised due to the increase in the release of volatile matter as temperature is raised. The ash yield in the 500- 
Table 3

Ultimate analysis (wt.\%) of the organic liquid obtained in the steam pyrolysis of pinewood in the $500-800{ }^{\circ} \mathrm{C}$ range.

\begin{tabular}{lllll}
\hline & $\begin{array}{l}500{ }^{\circ} \mathrm{C} \\
\text { Steam } / \mathrm{N}_{2}{ }^{\mathrm{a}}\end{array}$ & $\begin{array}{l}600{ }^{\circ} \mathrm{C} \\
\text { Steam } / \mathrm{N}_{2}{ }^{\mathrm{a}}\end{array}$ & $700{ }^{\circ} \mathrm{C}$ & $800{ }^{\circ} \mathrm{C}$ \\
\hline Carbon & $42.6 / 41.7$ & $45.0 / 40.6$ & 46.8 & 56.0 \\
Hydrogen & $8.3 / 8.2$ & $8.3 / 8.9$ & 8.6 & 8.1 \\
Oxygen & $49.1 / 50.1$ & $46.7 / 50.5$ & 44.6 & 35.9 \\
\hline H/C & $2.36 / 2.34$ & $2.22 / 2.61$ & 2.20 & 1.73 \\
O/C & $0.86 / 0.90$ & $0.78 / 0.94$ & 0.71 & 0.48 \\
\hline
\end{tabular}

${ }^{\text {a }}$ Results obtained in a previous pyrolysis study using $\mathrm{N}_{2}$ as fluidizing agent [7].

$600{ }^{\circ} \mathrm{C}$ temperature range is rather low ( 1.7 and $2.8 \mathrm{wt} \%$ at 500 and $600{ }^{\circ} \mathrm{C}$, respectively), which is due to the low amount of ash in the biomass raw material. The slight increase in the ash yield at $600{ }^{\circ} \mathrm{C}$ is a consequence of the higher volatile matter released by enhancing devolatilization and cracking reactions, with the ashes being retained within the carbonaceous matrix [10]. Nevertheless, the ash yields obtained at 700 and $800{ }^{\circ} \mathrm{C}$ are significantly higher, 8.5 and $10.5 \mathrm{wt} \%$, respectively. In fact, there is a significant extent of char steam gasification reactions at these temperatures, which promote the conversion of char into hydrogen rich gas.

These results are also reflected on the elemental analysis. Thus, the carbon content follows two different trends: firstly, as temperature is increased from $500{ }^{\circ} \mathrm{C}$ to $600{ }^{\circ} \mathrm{C}$, carbon content increases from 83.72 to $89.98 \mathrm{wt} \%$, respectively. Then, as temperature is increased further, carbon content decreases to 86.64 and $78.03 \mathrm{wt} \%$ at 700 and $800{ }^{\circ} \mathrm{C}$, respectively. The lower carbon content at $700{ }^{\circ} \mathrm{C}$ compared to the lower temperatures is due to the increase in the ash yield. Oxygen concentration also follows different trends, as it decreases from 11.54 to $3.56 \mathrm{wt} \%$ when temperature is increased from 500 to $700{ }^{\circ} \mathrm{C}$, but increases to $9.54 \mathrm{wt} \%$ when the run is conducted at $800^{\circ} \mathrm{C}$. Thus, Zhang et al. [88] reported that, in the steam gasification process, the $O$ content on the char surface increased due to $\mathrm{H}_{2} \mathrm{O}$ dissociation into $\mathrm{O}$ or $\mathrm{O}-$ containing radicals, which may react with char to form various Ocontaining intermediates (complexes). The increase in $\mathrm{O}$ content at the initial stages of char gasification was also observed by Alvarez et al. [89], who analyzed the evolution of biomass char features

Table 4

Influence of temperature on the char properties.

\begin{tabular}{lllll}
\hline Properties & $\begin{array}{l}500{ }^{\circ} \mathrm{C} \\
\text { Steam } / \mathrm{N}_{2}{ }^{\mathrm{a}}\end{array}$ & $\begin{array}{l}600{ }^{\circ} \mathrm{C} \\
\text { Steam/ } / \mathrm{N}_{2}{ }^{\mathrm{a}}\end{array}$ & $700{ }^{\circ} \mathrm{C}$ & $800{ }^{\circ} \mathrm{C}$ \\
\hline Ultimate analysis (wt.\%) & & & & \\
$\mathrm{C}$ & $83.7 / 82.7$ & $90.0 / 89.4$ & 86.64 & 78.03 \\
$\mathrm{H}$ & $2.9 / 2.9$ & $1.4 / 1.4$ & 1.21 & 1.89 \\
$\mathrm{~N}$ & $0.1 / 0.1$ & $0.1 / 0.1$ & 0.09 & 0.09 \\
$\mathrm{O}$ & $11.5 / 11.4$ & $5.7 / 5.7$ & 3.56 & 9.54 \\
Proximate analysis (wt.\%) & & & & \\
Volatile matter & $23.8 / 23.5$ & $20.7 / 14.1$ & 12.5 & 7.4 \\
Fixed carbon & $74.5 / 73.6$ & $76.5 / 82.5$ & 79.0 & 82.2 \\
Ash & $1.7 / 2.9$ & $2.8 / 3.4$ & 8.5 & 10.5 \\
\hline H/C & $0.42 / 0.42$ & $0.19 / 0.19$ & 0.17 & 0.29 \\
O/C & $0.10 / 0.10$ & $0.05 / 0.05$ & 0.03 & 0.09 \\
\hline HHV (MJ kg $\left.{ }^{-1}\right)^{\mathrm{b}}$ & 30.63 & 31.26 & 29.98 & 27.77 \\
\hline Surface characteristics & & & & \\
BET surface $\left(\mathrm{m}^{2} \mathrm{~g}^{-1}\right)$ & $16.5 / 16.2$ & $72.9 / 73.2$ & 138.3 & 495.0 \\
Micropore surface $\left(\mathrm{m}^{2} \mathrm{~g}^{-1}\right)$ & 13.8 & 68.4 & 114.8 & 359.5 \\
Average pore diameter $(\AA)$ & $380.0 / 389.2$ & $40.5 / 64.6$ & 33.0 & 32.5 \\
\hline
\end{tabular}

${ }^{\mathrm{a}}$ Results obtained in a previous pyrolysis study using $\mathrm{N}_{2}$ as fluidizing agent [7].

b $H H V=0.328 C+1.4306 H-0.0237 N+0.0929 S-(1-A / 100) \cdot(40.11 H / C)+0.346$; where $\mathrm{C}, \mathrm{H}, \mathrm{S}, \mathrm{O}, \mathrm{N}$ and $\mathrm{A}$ are the mass percentages on a dry basis of carbon, hydrogen, sulfur, oxygen, nitrogen and ash content of the fuels, respectively [87]. during steam gasification in the $800-900{ }^{\circ} \mathrm{C}$ temperature range.

These values are also evidence that use of steam as fluidizing agent has negligible influence on the properties of the chars obtained at low pyrolysis temperatures $\left(500-600^{\circ} \mathrm{C}\right)$, since similar trends have been reported in previous biomass pyrolysis studies conducted with $\mathrm{N}_{2}$ as fluidizing agent [7,10]. At $700{ }^{\circ} \mathrm{C}$, the results show that, although steam may take part in gasification reactions, char gasification kinetic is rather low, and therefore the influence of pyrolysis temperature on the char properties is not of great significance. However, at $800^{\circ} \mathrm{C}$, despite the short duration of the runs (of around $10 \mathrm{~min}$ ), steam has a considerable influence on the char properties.

It is noteworthy that the calorific values of all the char samples are higher than those of other conventional solid fuels, such as lignite or coal, which make them suitable for their further valorisation for energy production. Moreover, higher calorific values were observed for the chars samples obtained at 500 and $600{ }^{\circ} \mathrm{C}$ using steam instead of $\mathrm{N}_{2}$ as fluidizing agent [7]. Pütün et al. [90] also reported better char properties when they used steam in the pyrolysis of olive residues under different atmospheres.

The physical properties of the chars are also displayed in Table 4. As observed, the char obtained at $500{ }^{\circ} \mathrm{C}$ is composed of mainly mesopores, with the BET surface area being rather low $\left(16.2 \mathrm{~m}^{2} \mathrm{~g}^{-1}\right)$. As temperature is increased, microporosity is enhanced, which leads to the improvement of the surface area from $72.9 \mathrm{~m}^{2} \mathrm{~g}^{-1}$ at $600{ }^{\circ} \mathrm{C}$ to $495 \mathrm{~m}^{2} \mathrm{~g}^{-1}$ at $800{ }^{\circ} \mathrm{C}$. Alvarez et al. [89] reported the formation of micropores at $800{ }^{\circ} \mathrm{C}$ in the steam gasification, which they attributed to the slow gasification kinetics at this temperature, as this allows a better diffusion of steam through the narrow pores. These results are of great relevance for the application of the solid product as active carbon. Thus, the high surface area obtained at $800{ }^{\circ} \mathrm{C}$ confers commercial value upon the solid product and improves the overall economy of the pyrolysisreforming strategy.

Fig. 5 shows the SEM images of the chars obtained in the $500-800{ }^{\circ} \mathrm{C}$ range. As observed, all char samples have amorphous and heterogeneous structure, with considerable differences between lengthwise and cross sectional cuts. In the cross section SEM images of the char samples obtained in the $500-700{ }^{\circ} \mathrm{C}$ range, development of longitudinal cells with a diameter of around $10 \mu \mathrm{m}$ is evident. Moreover, well-defined grooves are also observed, which confer roughness upon the char samples. As temperature is increased, two main facts are revealed: i) deeper and better defined grooves due to more severe reaction conditions and, ii) the formation of smaller pores, which is consistent with the previous results of $\mathrm{N}_{2}$ adsorption-desorption.

At $800{ }^{\circ} \mathrm{C}$, the influence of steam on the char sample is also evident in the SEM images. Although well-formed cells are observed in the char (Fig. 5g), fractures are also evident in the structure due to gasification reactions. It should be noted that full conversion of the char particles has not been attained, as the steam pyrolysis runs were performed for $10 \mathrm{~min}$, and these images correspond therefore to the initial stages of char gasification reactions. In addition, Fig. $5 \mathrm{~h}$ reveals an incipient disintegration of the grooves, as well as a further development of microporosity in the char structure.

\section{Conclusions}

The conical spouted bed reactor has proven to perform well in the steam pyrolysis of pinewood sawdust. The influence of pyrolysis temperature on the product yields has been analyzed in the $500-800{ }^{\circ} \mathrm{C}$ range using steam as fluidizing agent.

An increase in reaction temperature greatly influences the product distribution and the composition of the gaseous and liquid 
compounds. Thus, the gas production increases as temperature is raised, whereas bio-oil and solid char fractions decrease.

At low pyrolysis temperatures $\left(500-600{ }^{\circ} \mathrm{C}\right)$, use of steam as fluidizing agent instead of $\mathrm{N}_{2}$ has hardly any influence on either the product yields or their composition. At $700{ }^{\circ} \mathrm{C}$, the low gas production and high bio-oil yield obtained are evidence of the low involvement of steam in the reaction mechanisms, which is due to the short residence time in the CSBR and the low rates of the reforming reactions. Conversely, at $800{ }^{\circ} \mathrm{C}$, the reaction pathway is controlled by gasification reactions, i.e., steam reforming and char heterogeneous gasification.

The composition of the bio-oil reveals that an increase in temperature leads to the formation of more stable compounds. Thus, phenols are the main fraction in the $500-700{ }^{\circ} \mathrm{C}$ range, whereas the primary products derived from biomass pyrolysis are almost fully transformed at $800{ }^{\circ} \mathrm{C}$, and a hydrocarbon fraction made up of polycyclic aromatic hydrocarbons (PAHs) is the main one.

The features of the char samples obtained at different temperatures are suitable for their use as energy source or further valorisation to produce active carbon.

The detailed analysis of the pyrolysis products approached in this study is of uttermost significance for future research studies wherein the main routes for $\mathrm{H}_{2}$ production, as well the main
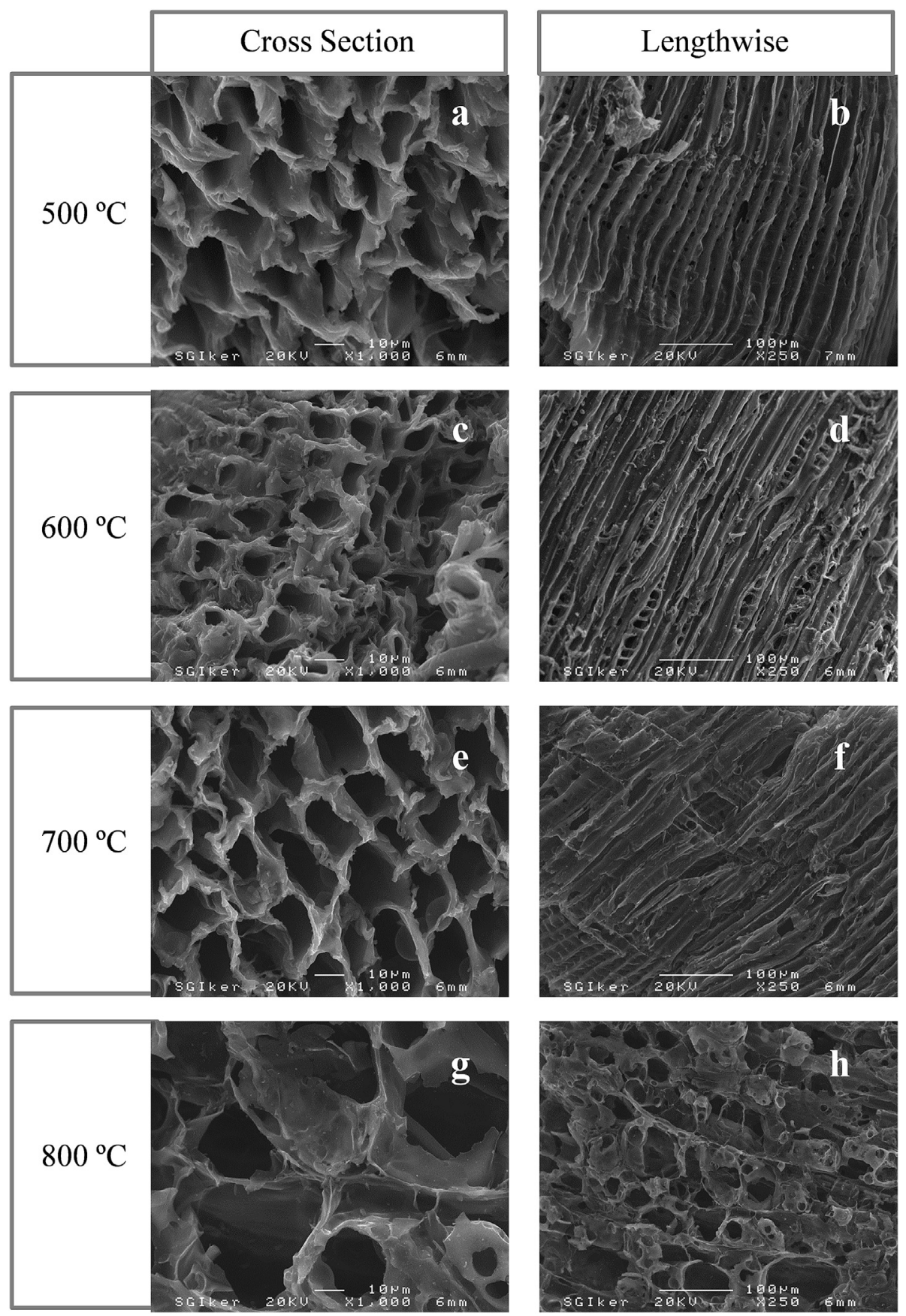

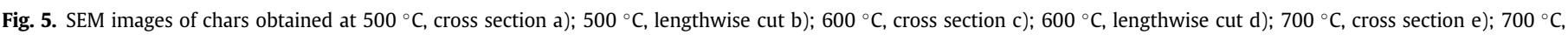
lengthwise cut f); $800{ }^{\circ} \mathrm{C}$, cross section g); and $800^{\circ} \mathrm{C}$, lengthwise cut $\mathrm{h}$ ). 
mechanisms of catalyst deactivation, will be analyzed in the twostep process of pyrolysis and in-line catalytic steam reforming.

\section{Author statement}

Enara Fernandez: Investigation, Visualization, Writing - review \& editing, Laura Santamaria: Writing - original draft, Visualization, Writing - review \& editing, Maider Amutio: Writing original draft, Conceptualization, Writing - review \& editing, Visualization, Supervision, Project administration, Funding acquisition, Maite Artetxe: Conceptualization, Writing - review \& editing, Visualization, Supervision, Project administration, Funding acquisition, Aitor Arregi: Validation, Visualization, Writing - review \& editing, Gartzen Lopez: Conceptualization, Validation, Writing - review \& editing, Visualization, Supervision, Project administration. Javier Bilbao: Writing - review \& editing, Visualization, Supervision, Project administration, Funding acquisition, Martin Olazar: Writing - review \& editing, Visualization, Supervision, Project administration, Funding acquisition.

\section{Declaration of competing interest}

The authors declare that they have no known competing financial interests or personal relationships that could have appeared to influence the work reported in this paper.

\section{Acknowledgments}

This work was carried out with the financial support from Spain's ministries of Science, Innovation and Universities (RTI2018101678-B-I00 (MCIU/AEI/FEDER, UE) and RTI2018-098283-J-I00 (MCIU/AEI/FEDER, UE)) and Science and Innovation (PID2019107357RB-I00 (AEI/FEDER, UE)) and the Basque Government (IT1218-19 and KK-2020/00107). Moreover, this project has received funding from the European Union's Horizon 2020 research and innovation programme under the Marie Sklodowska-Curie grant agreement No 823745.

\section{References}

[1] Sharifzadeh M, Sadeqzadeh M, Guo M, Borhani TN, Murthy Konda NVSN, Garcia MC, Wang L, Hallett J, Shah N. The multi-scale challenges of biomass fast pyrolysis and bio-oil upgrading: review of the state of art and future research directions. Prog Energy Combust Sci 2019;71:1-80. https://doi.org/ 10.1016/j.pecs.2018.10.006.

[2] Ong HC, Chen W, Farooq A, Gan YY, Lee KT, Ashokkumar V. Catalytic thermochemical conversion of biomass for biofuel production: a comprehensive review. Renew Sustain Energy Rev 2019;113:109266. https://doi.org/10.1016/ j.rser.2019.109266.

[3] Brown TR, Zhang Y, Hu G, Brown RC. Techno-economic analysis of biobased chemicals production via integrated catalytic processing. Biofuel Bioprod Biorefining 2012;6:73-87. https://doi.org/10.1002/bbb.344.

[4] Perkins G, Bhaskar T, Konarova M. Process development status of fast pyrolysis technologies for the manufacture of renewable transport fuels from biomass. Renew Sustain Energy Rev 2018;90:292-315. https://doi.org/ 10.1016/j.rser.2018.03.048.

[5] Venderbosch RH, Prins W. Fast pyrolysis technology development. Biofuels, Bioprod Biorefin 2010;4:178-208. https://doi.org/10.1002/bbb.205.

[6] Guedes RE, Luna AS, Torres AR. Operating parameters for bio-oil production in biomass pyrolysis: a review. J Anal Appl Pyrolysis 2018;129:134-49. https:// doi.org/10.1016/j.jaap.2017.11.019.

[7] Amutio M, Lopez G, Artetxe M, Elordi G, Olazar M, Bilbao J. Influence of temperature on biomass pyrolysis in a conical spouted bed reactor. Resour Conserv Recycl 2012;59:23-31. https://doi.org/10.1016/ j.resconrec.2011.04.002.

[8] Makibar J, Fernandez-Akarregi AR, Amutio M, Lopez G, Olazar M. Performance of a conical spouted bed pilot plant for bio-oil production by poplar flash pyrolysis. Fuel Process Technol 2015;137:283-9. https://doi.org/10.1016/ j.fuproc.2015.03.011.

[9] Amutio M, Lopez G, Alvarez J, Olazar M, Bilbao J. Fast pyrolysis of eucalyptus waste in a conical spouted bed reactor. Bioresour Technol 2015;194:225-32. https://doi.org/10.1016/j.biortech.2015.07.030.
[10] Alvarez J, Hooshdaran B, Cortazar M, Amutio M, Lopez G, Freire FB, Haghshenasfard M, Hosseini SH, Olazar M. Valorization of citrus wastes by fast pyrolysis in a conical spouted bed reactor. Fuel 2018;224:111-20. https:// doi.org/10.1016/j.fuel.2018.03.028.

[11] Azizi K, Keshavarz Moraveji M, Arregi A, Amutio M, Lopez G, Olazar M. On the pyrolysis of different microalgae species in a conical spouted bed reactor: biofuel yields and characterization. Bioresour Technol 2020;311:123561. https:// doi.org/10.1016/j.biortech.2020.123561.

[12] Makibar J, Fernandez-Akarregi AR, Alava I, Cueva F, Lopez G, Olazar M. Investigations on heat transfer and hydrodynamics under pyrolysis conditions of a pilot-plant draft tube conical spouted bed reactor. Chem Eng Process Process Intensif 2011;50:790-8. https://doi.org/10.1016/j.cep.2011.05.013.

[13] Garcia-Nunez JA, Pelaez-Samaniego MR, Garcia-Perez ME, Fonts I, Abrego J, Westerhof RJM, Garcia-Perez M. Historical developments of pyrolysis reactors: a review. Energy Fuels 2017;31:5751-75. https://doi.org/10.1021/ acs.energyfuels.7b00641.

[14] Hu X, Gholizadeh M. Biomass pyrolysis: a review of the process development and challenges from initial researches up to the commercialisation stage. J Energy Chem 2019;39:109-43. https://doi.org/10.1016/ j.jechem.2019.01.024.

[15] Valle B, Remiro A, García-Gómez N, Gayubo AG, Bilbao J. Recent research progress on bio-oil conversion into bio-fuels and raw chemicals: a review. J Chem Technol Biotechnol 2019;94:670-89. https://doi.org/10.1002/ jctb. 5758 .

[16] Dabros TMH, Stummann MZ, Høj M, Jensen PA, Grunwaldt J-, Gabrielsen J, Mortensen PM, Jensen AD. Transportation fuels from biomass fast pyrolysis, catalytic hydrodeoxygenation, and catalytic fast hydropyrolysis. Prog Energy Combust Sci 2018;68:268-309. https://doi.org/10.1016/j.pecs.2018.05.002.

[17] Baloch HA, Nizamuddin S, Siddiqui MTH, Riaz S, Jatoi AS, Dumbre DK, Mubarak NM, Srinivasan MP, Griffin GJ. Recent advances in production and upgrading of bio-oil from biomass: a critical overview. J Environ Chem Eng 2018;6:5101-18. https://doi.org/10.1016/j.jece.2018.07.050.

[18] Cao Z, Niu J, Gu Y, Zhang R, Liu Y, Luo L. Catalytic pyrolysis of rice straw: screening of various metal salts, metal basic oxide, acidic metal oxide and zeolite catalyst on products yield and characterization. J Clean Prod 2020;269: 122079. https://doi.org/10.1016/j.jclepro.2020.122079.

[19] Sorunmu Y, Billen P, Spatari S. A review of thermochemical upgrading of pyrolysis bio-oil: techno-economic analysis, life cycle assessment, and technology readiness. GCB Bioenergy 2020;12:4-18. https://doi.org/10.1111/ gcbb. 12658 .

[20] Guan G, Kaewpanha M, Hao X, Abudula A. Catalytic steam reforming of biomass tar: prospects and challenges. Renew Sustain Energy Rev 2016;58: 450-61. https://doi.org/10.1016/j.rser.2015.12.316.

[21] Nabgan W, Tuan Abdullah TA, Mat R, Nabgan B, Gambo Y, Ibrahim M, Ahmad A, Jalil AA, Triwahyono S, Saeh I. Renewable hydrogen production from bio-oil derivative via catalytic steam reforming: an overview. Renew Sustain Energy Rev 2017;79:347-57. https://doi.org/10.1016/ j.rser.2017.05.069.

[22] Pandey B, Prajapati YK, Sheth PN. Recent progress in thermochemical techniques to produce hydrogen gas from biomass: a state of the art review. Int J Hydrogen Energy 2019;44:25384-415. https://doi.org/10.1016/ j.ijhydene.2019.08.031.

[23] Arregi A, Amutio M, Lopez G, Bilbao J, Olazar M. Evaluation of thermochemical routes for hydrogen production from biomass: a review. Energy Convers Manag 2018;165:696-719. https://doi.org/10.1016/j.enconman.2018.03.089.

[24] Lopez G, Garcia I, Arregi A, Santamaria L, Amutio M, Artetxe M, Bilbao J, Olazar M. Thermodynamic assessment of the oxidative steam reforming of biomass fast pyrolysis volatiles. Energy Convers Manag 2020;214:112889. https://doi.org/10.1016/j.enconman.2020.112889.

[25] Arregi A, Lopez G, Amutio M, Barbarias I, Bilbao J, Olazar M. Hydrogen production from biomass by continuous fast pyrolysis and in-line steam reforming. RSC Adv 2016;6:25975-85. https://doi.org/10.1039/c6ra01657j.

[26] Ochoa A, Bilbao J, Gayubo AG, Castaño P. Coke formation and deactivation during catalytic reforming of biomass and waste pyrolysis products: a review. Renew Sustain Energy Rev 2020;119:109600. https://doi.org/10.1016/ j.rser.2019.109600.

[27] Santamaria L, Lopez G, Arregi A, Amutio M, Artetxe M, Bilbao J, Olazar M. Stability of different Ni supported catalysts in the in-line steam reforming of biomass fast pyrolysis volatiles. Appl Catal, B 2019;242:109-20. https:// doi.org/10.1016/j.apcatb.2018.09.081.

[28] Santamaria L, Artetxe M, Lopez G, Cortazar M, Amutio M, Bilbao J, Olazar M. Effect of $\mathrm{CeO}_{2}$ and $\mathrm{MgO}$ promoters on the performance of a $\mathrm{Ni} / \mathrm{Al}_{2} \mathrm{O}_{3}$ catalyst in the steam reforming of biomass pyrolysis volatiles. Fuel Process Technol 2020;198:106223. https://doi.org/10.1016/j.fuproc.2019.106223.

[29] Arregi A, Lopez G, Amutio M, Artetxe M, Barbarias I, Bilbao J, Olazar M. Role of operating conditions in the catalyst deactivation in the in-line steam reforming of volatiles from biomass fast pyrolysis. Fuel 2018;216:233-44. https://doi.org/10.1016/j.fuel.2017.12.002.

[30] Valderrama Rios ML, González AM, Lora EES, Almazán del Olmo OA. Reduction of tar generated during biomass gasification: a review. Biomass Bioenergy 2018;108:345-70. https://doi.org/10.1016/j.biombioe.2017.12.002.

[31] Parthasarathy P, Narayanan KS. Hydrogen production from steam gasification of biomass: influence of process parameters on hydrogen yield - a review. Renew Energy 2014;66:570-9. https://doi.org/10.1016/j.renene.2013.12.025.

[32] Önal EP, Uzun BB, Pütün AE. Steam pyrolysis of an industrial waste for bio-oil 
production. Fuel Process Technol 2011;92:879-85. https://doi.org/10.1016/ j.fuproc.2010.12.006.

[33] Özbay N, Pütün AE, Pütün E. Structural analysis of bio-oils from pyrolysis and steam pyrolysis of cottonseed cake. J Anal Appl Pyrolysis 2001;60:89-101. https://doi.org/10.1016/S0165-2370(00)00161-3.

[34] Önal E, Uzun BB, Pütün AE. The effect of pyrolysis atmosphere on bio-oil yields and structure. Int J Green Energy 2017;14:1-8. https://doi.org/10.1080/ 15435075.2014.952421.

[35] Pütün A, Özbay N, Pütün E. Effect of steam on the pyrolysis of biomass. Energy Sources Part A 2006;28:253-62. https://doi.org/10.1080/009083190890012.

[36] Kantarelis E, Yang W, Blasiak W. Production of liquid feedstock from biomass via steam pyrolysis in a fluidized bed reactor. Energy Fuels 2013;27:4748-59. https://doi.org/10.1021/ef400580x.

[37] Garcia L, Salvador ML, Arauzo J, Bilbao R. Influence of the reaction atmosphere on gas production and composition in the catalytic conversion of biomass. In: Bridgwater AV, editor. Progress in thermochemical biomass conversion; 2001. p. 346-57.

[38] Ateş F, Pütün AE, Pütün E. Catalytic pyrolysis of perennial shrub, Euphorbia rigida in the water vapour atmosphere. J Anal Appl Pyrolysis 2005;73: 299-304. https://doi.org/10.1016/j.jaap.2005.02.007.

[39] Pütün E, Ateş F, Pütün AE. Catalytic pyrolysis of biomass in inert and steam atmospheres. Fuel 2008;87:815-24. https://doi.org/10.1016/ j.fuel.2007.05.042.

[40] Kantarelis E, Yang W, Blasiak W. Effects of silica-supported nickel and vanadium on liquid products of catalytic steam pyrolysis of biomass. Energy Fuels 2014;28:591-9. https://doi.org/10.1021/ef401939g.

[41] Kantarelis E, Yang W, Blasiak W. Effect of zeolite to binder ratio on product yields and composition during catalytic steam pyrolysis of biomass over transition metal modified HZSM5. Fuel 2014;122:119-25. https://doi.org/ 10.1016/j.fuel.2013.12.054.

[42] Zhang Z, Zhu Z, Shen B, Liu L. Insights into biochar and hydrochar production and applications: a review. Energy 2019;171:581-98. https://doi.org/ 10.1016/j.energy.2019.01.035.

[43] Orozco S, Alvarez J, Lopez G, Artetxe M, Bilbao J, Olazar M. Pyrolysis of plastic wastes in a fountain confined conical spouted bed reactor: determination of stable operating conditions. Energy Convers Manag 2021;229:113768. https://doi.org/10.1016/j.enconman.2020.113768.

[44] Amutio M, Lopez G, Aguado R, Artetxe M, Bilbao J, Olazar M. Effect of vacuum on lignocellulosic biomass flash pyrolysis in a conical spouted bed reactor. Energy Fuels 2011;25:3950-60. https://doi.org/10.1021/ef200712h.

[45] Alvarez J, Amutio M, Lopez G, Barbarias I, Bilbao J, Olazar M. Sewage sludge valorization by flash pyrolysis in a conical spouted bed reactor. Chem Eng J 2015;273:173-83. https://doi.org/10.1016/j.cej.2015.03.047.

[46] Zhou B, Dichiara A, Zhang Y, Zhang Q Zhou J. Tar formation and evolution during biomass gasification: an experimental and theoretical study. Fuel 2018;234:944-53. https://doi.org/10.1016/j.fuel.2018.07.105.

[47] Shen Y, Yoshikawa K. Recent progresses in catalytic tar elimination during biomass gasification or pyrolysis - a review. Renew Sustain Energy Rev 2013;21:371-92. https://doi.org/10.1016/j.rser.2012.12.062.

[48] Kan T, Strezov V, Evans TJ. Lignocellulosic biomass pyrolysis: a review of product properties and effects of pyrolysis parameters. Renew Sustain Energy Rev 2016;57:126-1140. https://doi.org/10.1016/j.rser.2015.12.185.

[49] Akhtar J, Saidina Amin N. A review on operating parameters for optimum liquid oil yield in biomass pyrolysis. Renew Sustain Energy Rev 2012;16: 5101-9. https://doi.org/10.1016/j.rser.2012.05.033.

[50] Haykiri-Acma H, Yaman S, Kucukbayrak S. Comparison of the thermal reactivities of isolated lignin and holocellulose during pyrolysis. Fuel Process Technol 2010;91:759-64. https://doi.org/10.1016/j.fuproc.2010.02.009.

[51] Di Blasi C. Combustion and gasification rates of lignocellulosic chars. Prog Energy Combust Sci 2009;35:121-40. https://doi.org/10.1016/ j.pecs.2008.08.001.

[52] González-Vázquez MP, García R, Gil MV, Pevida C, Rubiera F. Comparison of the gasification performance of multiple biomass types in a bubbling fluidized bed. Energy Convers Manag 2018;176:309-23. https://doi.org/10.1016/ j.enconman.2018.09.020.

[53] Ahmed A, Abu Bakar MS, Sukri RS, Hussain M, Farooq A, Moogi S, Park Y. Sawdust pyrolysis from the furniture industry in an auger pyrolysis reactor system for biochar and bio-oil production. Energy Convers Manag 2020;226: 113502. https://doi.org/10.1016/j.enconman.2020.113502.

[54] Erkiaga A, Lopez G, Amutio M, Bilbao J, Olazar M. Influence of operating conditions on the steam gasification of biomass in a conical spouted bed reactor. Chem Eng J 2014;237:259-67. https://doi.org/10.1016/ j.cej.2013.10.018

[55] Göransson K, Söderlind U, Zhang W. Experimental test on a novel dual fluidised bed biomass gasifier for synthetic fuel production. Fuel 2011;90: 1340-9. https://doi.org/10.1016/j.fuel.2010.12.035.

[56] Zhang Z, Pang S. Experimental investigation of biomass devolatilization in steam gasification in a dual fluidised bed gasifier. Fuel 2017;188:628-35. https://doi.org/10.1016/j.fuel.2016.10.074.

[57] Rapagnà S, Jand N, Kiennemann A, Foscolo PU. Steam-gasification of biomass in a fluidised-bed of olivine particles. Biomass Bioenergy 2000;19:187-97. https://doi.org/10.1016/S0961-9534(00)00031-3.

[58] Xiao Y, Xu S, Song Y, Shan Y, Wang C, Wang G. Biomass steam gasification for hydrogen-rich gas production in a decoupled dual loop gasification system. Fuel Process Technol 2017;165:54-61. https://doi.org/10.1016/ j.fuproc.2017.05.013.

[59] Fremaux S, Beheshti S-, Ghassemi H, Shahsavan-Markadeh R. An experimental study on hydrogen-rich gas production via steam gasification of biomass in a research-scale fluidized bed. Energy Convers Manag 2015;91:427-32. https:// doi.org/10.1016/j.enconman.2014.12.048.

[60] Cortazar M, Lopez G, Alvarez J, Amutio M, Bilbao J, Olazar M. Advantages of confining the fountain in a conical spouted bed reactor for biomass steam gasification. Energy 2018;153:455-63. https://doi.org/10.1016/ j.energy.2018.04.067.

[61] Cortazar M, Lopez G, Alvarez J, Amutio M, Bilbao J, Olazar M. Behaviour of primary catalysts in the biomass steam gasification in a fountain confined spouted bed. Fuel 2019;253:1446-56. https://doi.org/10.1016/ j.fuel.2019.05.094.

[62] Ren J, Cao JP, Zhao XY, Yang FL, Wei XY. Recent advances in syngas production from biomass catalytic gasification: a critical review on reactors, catalysts, catalytic mechanisms and mathematical models. Renew Sustain Energy Rev 2019;116:109426. https://doi.org/10.1016/j.rser.2019.109426.

[63] Uddin MN, Daud WMAW, Abbas HF. Effects of pyrolysis parameters on hydrogen formations from biomass: a review. RSC Adv 2014;4:10467-90. https://doi.org/10.1039/c3ra43972k.

[64] Dascomb J, Krothapalli A, Fakhrai R. Thermal conversion efficiency of producing hydrogen enriched syngas from biomass steam gasification. Int J

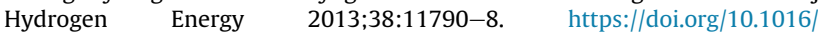
j.ijhydene.2013.07.022

[65] Cortazar M, Alvarez J, Lopez G, Amutio M, Santamaria L, Bilbao J, Olazar M. Role of temperature on gasification performance and tar composition in a fountain enhanced conical spouted bed reactor. Energy Convers Manag 2018;171:1589-97. https://doi.org/10.1016/j.enconman.2018.06.071.

[66] Karmakar MK, Datta AB. Generation of hydrogen rich gas through fluidized bed gasification of biomass. Bioresour Technol 2011;102:1907-13. https:// doi.org/10.1016/j.biortech.2010.08.015.

[67] Shen D, Jin W, Hu J, Xiao R, Luo K. An overview on fast pyrolysis of the main constituents in lignocellulosic biomass to valued-added chemicals: structures, pathways and interactions. Renew Sustain Energy Rev 2015;51:761-74. https://doi.org/10.1016/j.rser.2015.06.054.

[68] Wang S, Dai G, Yang H, Luo Z. Lignocellulosic biomass pyrolysis mechanism: a state-of-the-art review. Prog Energy Combust Sci 2017;62:33-86. https:// doi.org/10.1016/j.pecs.2017.05.004.

[69] Zong P, Jiang Y, Tian Y, Li J, Yuan M, Ji Y, Chen M, Li D, Qiao Y. Pyrolysis behavior and product distributions of biomass six group components: starch, cellulose, hemicellulose, lignin, protein and oil. Energy Convers Manag 2020;216:112777. https://doi.org/10.1016/j.enconman.2020.112777.

[70] Font Palma C. Modelling of tar formation and evolution for biomass gasification: a review. Appl Energy 2013;111:129-41. https://doi.org/10.1016/ j.apenergy.2013.04.082.

[71] Hernández JJ, Ballesteros R, Aranda G. Characterisation of tars from biomass gasification: effect of the operating conditions. Energy 2013;50:333-42. https://doi.org/10.1016/j.energy.2012.12.005.

[72] Santamaria L, Beirow M, Mangold F, Lopez G, Olazar M, Schmid M, Li Z, Scheffknecht G. Influence of temperature on products from fluidized bed pyrolysis of wood and solid recovered fuel. Fuel 2021;283:118922. https:// doi.org/10.1016/j.fuel.2020.118922.

[73] Kawamoto H. Lignin pyrolysis reactions. J Wood Sci 2017;63:117-32. https:// doi.org/10.1007/s10086-016-1606-z.

[74] Huber GW, Iborra S, Corma A. Synthesis of transportation fuels from biomass: chemistry, catalysts, and engineering. Chem Rev 2006;106:4044-98. https:// doi.org/10.1021/cr068360d.

[75] Milne TA, Evans RJ, Abatzaglou N. Biomass gasifier "tars": their nature, formation, and conversion. NREL/TP-570-25357 1998.

[76] Li X, Zhang Z, Zhang L, Fan H, Li X, Liu Q, Wang S, Hu X. Investigation of coking behaviors of model compounds in bio-oil during steam reforming. Fuel 2020;265:116961. https://doi.org/10.1016/j.fuel.2019.116961.

[77] Chiaramonti D, Oasmaa A, Solantausta Y. Power generation using fast pyrolysis liquids from biomass. Renew Sustain Energy Rev 2007;11:1056-86. https://doi.org/10.1016/j.rser.2005.07.008.

[78] Demirbas A. The influence of temperature on the yields of compounds existing in bio-oils obtained from biomass samples via pyrolysis. Fuel Process Technol 2007;88:591-7. https://doi.org/10.1016/j.fuproc.2007.01.010.

[79] Echresh Zadeh Z, Abdulkhani A, Saha B. A comparative production and characterisation of fast pyrolysis bio-oil from Populus and Spruce woods. Energy 2021;214:118930. https://doi.org/10.1016/j.energy.2020.118930.

[80] Garg S, Das P. Microporous carbon from cashew nutshell pyrolytic biochar and its potential application as $\mathrm{CO}_{2}$ adsorbent. Biomass Convers Biorefin 2020;10: 1043-61. https://doi.org/10.1007/s13399-019-00506-1.

[81] Huang Y, Chiueh P, Shih C, Lo S, Sun L, Zhong Y, Qiu C. Microwave pyrolysis of rice straw to produce biochar as an adsorbent for $\mathrm{CO}_{2}$ capture. Energy 2015;84:75-82. https://doi.org/10.1016/j.energy.2015.02.026.

[82] Alvarez J, Lopez G, Amutio M, Bilbao J, Olazar M. Physical activation of rice husk pyrolysis char for the production of high surface area activated carbons. Ind Eng Chem Res 2015;54:7241-50. https://doi.org/10.1021/ acs.iecr.5b01589.

[83] Zhang L, Yao Z, Zhao L, Li Z, Yi W, Kang K, Jia J. Synthesis and characterization of different activated biochar catalysts for removal of biomass pyrolysis tar. Energy 2021;232:120927. https://doi.org/10.1016/j.energy.2021.120927.

[84] Patel H, Mangukiya H, Maiti P, Maiti S. Empty cotton boll crop-residue and 
plastic waste valorization to bio-oil, potassic fertilizer and activated carbon a bio-refinery model. J Clean Prod 2021;290:125738. https://doi.org/10.1016/ j.jclepro.2020.125738.

[85] Ghodake GS, Shinde SK, Kadam AA, Saratale RG, Saratale GD, Kumar M, Palem RR, Al-Shwaiman HA, Elgorban AM, Syed A, Kim D. Review on biomass feedstocks, pyrolysis mechanism and physicochemical properties of biochar: state-of-the-art framework to speed up vision of circular bioeconomy. J Clean Prod 2021;297:126645. https://doi.org/10.1016/j.jclepro.2021.126645.

[86] Chen YH, Schmid M, Chang CC, Chang CY, Scheffknecht G. Lab-scale investigation of palm shell char as tar reforming catalyst. Catalysts 2020;10:476. https://doi.org/10.3390/catal10050476.

[87] Grabosky M, Bain R. Properties of biomass relevant to gasification. Principles of gasification, vol. II. Colorado: A Survey of Biomass; 1979.

[88] Zhang S, Min Z, Tay HL, Asadullah M, Li CZ. Effects of volatile-char interactions on the evolution of char structure during the gasification of Victorian brown coal in steam. Fuel 2011;90:1529-35. https://doi.org/10.1016/ j.fuel.2010.11.010.

[89] Alvarez J, Lopez G, Amutio M, Bilbao J, Olazar M. Evolution of biomass char features and their role in the reactivity during steam gasification in a conical spouted bed reactor. Energy Convers Manag 2019;181:214-22. https:// doi.org/10.1016/j.enconman.2018.12.008.

[90] Pütün AE, Uzun BB, Apaydin E, Pütün E. Bio-oil from olive oil industry wastes: pyrolysis of olive residue under different conditions. Fuel Process Technol 2005;87:25-32. https://doi.org/10.1016/j.fuproc.2005.04.003. 